\title{
Perancangan Media Digital Interaktif Gamelan Jawa Timuran sebagai Wadah Pengenalan Alat Musik Tradisional untuk Anak Usia 9-10 Tahun
}

\author{
Lintang Rahmawati dan Rahmatsyam Lakoro. \\ Jurusan Desain Produk Industri, Fakultas Teknik Sipil dan Perencanaan, Institut Teknologi Sepuluh \\ Nopember (ITS) \\ Jl. Arief Rahman Hakim, Surabaya 60111 Indonesia \\ e-mail:ramok@prodes.its.ac.id
}

\begin{abstract}
Abstrak-Gamelan Jawa Timuran telah banyak mengalami perkembangan baik dari sisi instrumennya maupun dari segi fungsinya. Perkembangan ini terjadi karena adanya pengaruh dari beberapa pihak, salah satunya adalah masuknya budaya asing yang makin lama masuk tanpa terfilter dengan baik, dan berdampak pada bergesernya eksistensi gamelan Jawa Timuran. Semakin banyak masyarakat khususnya anak-anak yang kurang pengetahuan bahkan tidak memiliki minat mengenal gamelan Jawa Timuran. Pengetahuan anak yang minim salah satunya disebabkan oleh kurangnya pengenalan mengenai budaya ini. Karena itulah diperlukan media yang dapat membantu anak mengenal warisan budaya ini. Dengan melakukan Focus Group Discussion, dapat diketahui bahwa anak menganggap gamelan adalah sesuatu yang membosankan dan kuno. Anak cenderung lebih suka belajar alat musik dari budaya luar seperti piano, gitar, dan lain-lain daripada gamelan. Saat ini alternatif media yang dapat menjadi jembatan bagi anak untuk mengenal gamelan sangatlah dibutuhkan. Media digital interaktif dapat menjawab permasalahan tersebut. Selain berbentuk gabungan antara buku cerita dan game dengan disisipi teknik motion graphic yang menarik, anak juga bisa berinteraksi dengan alat musik pada gamelan Jawa Timuran secara virtual, sehingga masalah tidak adanya pengenalan bunyi pada media buku visual konvensional menjadi terpecahkan. Anak juga bisa belajar memainkan gendhing apabila disertakan contoh gendhing dan instruksi untuk memainkan gendhing tersebut.
\end{abstract}

Kata Kunci-Anak, Gamelan Jawa Timuran, Interaktif, Media Digital

\section{PENDAHULUAN}

$\mathrm{S}$ ETIAP daerah memiliki warisan budaya masing-masing yang harus dilestarikan dan diturunkan pada generasi muda untuk menjaga eksistensi warisan budaya tersebut, tidak terkecuali di Pulau Jawa. Salah satu warisan budaya di Jawa adalah gamelan Jawa Timuran. Gamelan Jawa Timuran merupakan seperangkat alat musik tradisional Jawa Timur yang dimainkan secara bersama-sama untuk membentuk sebuah harmoni, yang biasanya terdiri dari gong, kenong, gambang, bonang, kendhang, dan alat musik lainnya.

Gamelan Jawa Timuran telah banyak mengalami perkembangan baik dari sisi instrumennya maupun dari segi fungsinya. Perkembangan ini terjadi karena adanya pengaruh dari beberapa pihak, salah satunya adalah masuknya budaya- budaya asing dari luar. Semakin lama budaya-budaya asing ini masuk tanpa difilter dengan baik dan berdampak pada bergesernya popularitas gamelan Jawa Timuran. Faktanya, bahwa semakin lama semakin banyak masyarakat khususnya anak-anak yang tidak mengetahui secara detail mengenai gamelan Jawa Timuran, seperti nama instrumen dalam gamelan Jawa Timuran, bagaimana cara memainkannya, bagaimana bentuknya, dan bagaimana suaranya. Sudah bukan rahasia apabila mayoritas peminat gamelan Jawa Timuran adalah orang-orang berkewarganegaraan bangsa lain.

Pengetahuan anak-anak yang sangat minim mengenai gamelan Jawa Timuran salah satunya disebabkan oleh kurangnya pengenalan mengenai budaya ini sejak awal. Anakanak khususnya yang berdomisili di Jawa Timur mayoritas dibesarkan tanpa pengetahuan mengenai gamelan Jawa Timuran. Di sekolah pun anak hanya diperkenalkan sedikit mengenai gamelan.

Beberapa upaya yang sudah dilakukan untuk tetap menjaga eksistensi gamelan Jawa Timuran, misalnya dengan mengadakan pertunjukan karawitan, mendokumentasikan dalam buku, dan lain-lain. Sayangnya, semua itu hanya ditujukan untuk mereka yang memang sudah mengenal gamelan dan ingin melibatkan diri dengan gamelan lebih dalam lagi. Buku-buku referensi yang sudah ada pun kurang menarik untuk dibaca oleh masyarakat awam, khususnya anak-anak.

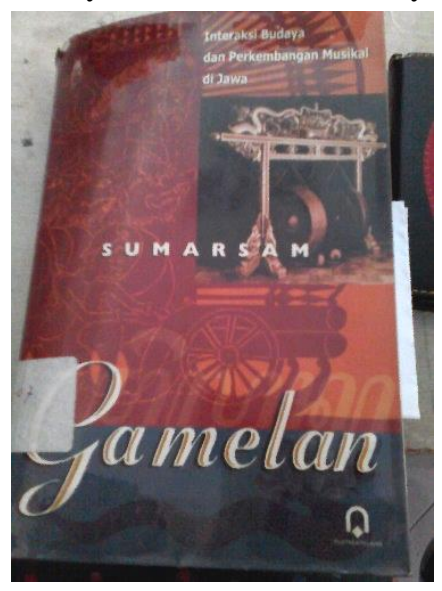

Gambar 1. Buku referensi gamelan: Interaksi Budaya dan Perkembangan Musikal di Jawa 
Buku ini ditulis memang dengan tujuan menjadi referensi, sehingga kurang cocok untuk menjadi media pengenalan alat musik tradisional khususnya gamelan Jawa Timuran untuk anak. Sangat jarang beredar di pasaran buku mengenai pengenalan gamelan yang menarik minat anak-anak. Ada pun ensiklopedia anak masih mengulas alat musik tradisional Indonesia secara umum.

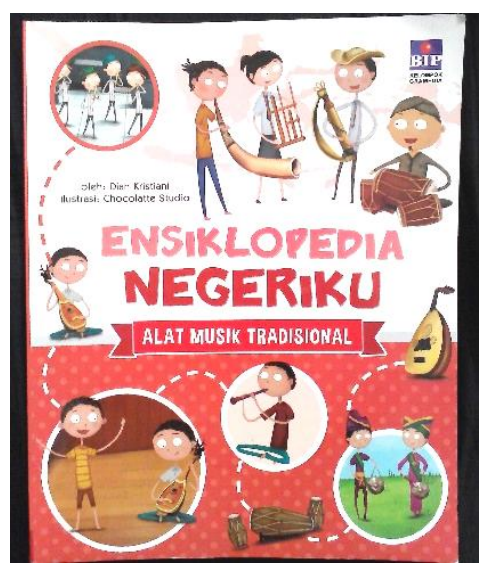

Gambar 2. Buku anak ensiklopedia Negeriku: Alat Musik Tradisional

Buku ini memang dikhususkan untuk anak-anak dengan melihat visual dan bahasa yang dipakai adalah bergaya khas anak-anak. Tetapi buku visual berupa ensiklopedia ini hanya membahas alat musik tradisional Indonesia secara keseluruhan, dan dampak dari buku ini untuk anak-anak hanya sebatas mengetahui nama, gambar, dan deskripsi singkat mengenai alat musik yang ada. "Alat musik" seharusnya tidak jauh dari "bunyi". Sedangkan objek dari buku ini adalah alat musik, dan pengenalan alat musik seharusnya juga disertai dengan pengetahuan bunyi yang dihasilkan instrumen.

Mengenalkan warisan budaya seperti gamelan Jawa Timuran sejak masih anak-anak sangatlah baik, melihat bahwa daya ingat anak-anak masih tinggi sehingga kemungkinan melupakan budaya asli Indonesia bisa diminimalisir. Menurut Dr. Kartini Kartono, seperti dilansir oleh Albert Herwindityo Wicaksono dalam laporan Tugas Akhirnya "Perancangan Education Toys tentang Pengenalan Tokoh-Tokoh Pahlawan Nasional Indonesia untuk Siswa Kelas 4 Sekolah Dasar", ingatan pada anak usia sekolah dasar mencapai intensitas paling besar dan paling kuat. Daya menghafal dan daya memorisasi (dengan sengaja memasukkan dan melekatkan pengetahuan dalam ingatan) adalah paling kuat. Dan anak mampu memuat jumlah materi ingatan paling banyak [1].

Dari permasalahan yang telah dijabarkan sebelumnya, dapat disimpulkan bahwa anak-anak memerlukan media baru untuk dapat mengenal gamelan Jawa Timuran. Materi bisa dipelajari oleh anak dari media apa pun, baik media cetak maupun media elektronik. Perkembangan teknologi yang pesat dan penggunaannya yang dominan pada hampir seluruh kegiatan masyarakat pada saat ini, bisa dijadikan sebagai ide awal untuk memecahkan masalah tersebut. Pada zaman seperti ini jarang sekali anak-anak dari kawasan perkotaan yang tidak bisa mengoperasikan komputer. Menurut siaran pers tentang riset Kementerian Komunikasi dan Informatika (KOMINFO) dan UNICEF mengenai perilaku anak dan remaja dalam menggunakan internet [2], saat ini ada sekitar 30 juta anak-anak dan remaja Indonesia yang merupakan pengguna internet, dan $69 \%$ di antaranya adalah pengguna komputer dan 34\% pengguna laptop. Sedangkan dari hasil survey dengan pengambilan sampel anak-anak usia 9-10 tahun, $87,5 \%$ di antaranya mengaku sudah terbiasa mengoperasikan komputer dan laptop.

Dari perilaku anak-anak yang sudah terbiasa mengoperasikan komputer tersebut, maka media berbasis digital cocok untuk menjadi media alternatif pengenalan gamelan Jawa Timuran, yaitu dalam bentuk media digital interaktif. Media ini dapat menutupi kelemahan buku visual konvensional yang tidak dapat mengeluarkan bunyi-bunyian. Selain itu, permainan digital interaktif juga menawarkan interaksi antara anak dengan instrumen-instrumen dalam gamelan Jawa Timuran. Media digital interaktif ini akan memancing rasa penasaran anak terhadap gamelan Jawa Timuran, sehingga dapat mendorong keinginan anak untuk mengenal lebih dalam mengenai gamelan Jawa Timuran.

\section{A. Batasan Masalah}

1. Media digital interaktif sebagai media pengenalan terhadap nama, bentuk, cara memainkan, pengelompokan jenis, peran, dan suara yang dihasilkan alat musik dalam gamelan Jawa Timuran, mulai dari kendhang, gender, gambang, slenthem, peking, saron, demung, bonang, kenong, kempul, kethuk, kempyang, sampai gong.

2. Perancangan ini berisi konten-konten dasar pengenalan gamelan Jawa Timuran dan tidak membahas gamelan Jawa Timuran lebih jauh sebagai kebutuhan referensi.

3. Perancangan ini tidak membahas metode pemasaran untuk tujuan komersil.

\section{B. Rumusan Masalah}

"Bagaimana merancang media digital interaktif sebagai wadah pengenalan gamelan Jawa Timuran kepada anak usia 910 tahun untuk meningkatkan pengetahuan dasar anak mengenai budaya lokal?"

\section{Tujuan}

1. Anak dapat mengenal gamelan Jawa Timuran dengan cara yang menarik.

2. Anak mendapat pengetahuan dasar mengenai gamelan Jawa Timuran.

\section{TINJAUAN PUSTAKA}

\section{A. Landasan Teori}

1. Media Digital Interaktif

Media digital interaktif termasuk dalam multimedia interaktif. Elaine England dan Andy Finney (2011:2) mengemukakan multimedia interaktif adalah sebuah integrasi dari media digital yang meliputi dari kombinasi teks elektronik, grafik, gambar bergerak, dan suara menjadi sebuah lingkungan digital yang terkomputerisasi dan terstruktur yang mengijinkan pengguna untuk berinteraksi dengan data-data yang telah ada untuk tujuan yang telah jelas.

Karakteristik dari multimedia interaktif antara lain:

- Memiliki lebih dari satu media yang konvergen, misalnya menggabungkan unsur audio dan visual. 
- Bersifat interaktif, memiliki kemampuan untuk mengakomodasi respon pengguna.

- Bersifat mandiri, dalam pengertian memberi kemudahan dan kelengkapan isi sehingga pengguna bisa menggunakan media tersebut tanpa bantuan orang lain.

- Memenuhi fungsi untuk memperkuat respon pengguna secepatnya dan sesering mungkin.

2. Gamelan Jawa Timuran

Gamelan Jawa merupakan seperangkat alat musik tradisional Jawa yang dimainkan secara bersama-sama untuk membentuk sebuah harmoni. Mayoritas alat musik pada gamelan Jawa terbuat dari campuran perunggu dan kuningan, walaupun ada pula yang terbuat dari besi. Sisanya terbuat dari kayu dan kulit sapi/kerbau.

Setiap etnik di Indonesia memiliki warna musiknya masingmasing, begitu pula dengan Jawa Timur. Maka dari itu tidaklah aneh bahwa Jawa Timur memiliki gamelannya sendiri. Gamelan Jawa Timuran biasanya terdiri dari 12-15 alat musik. Berikut ini alat-alat musik yang terdapat dalam perangkat gamelan Jawa Timuran:

- Kendhang (Kendhang Jawa Timuran, Kendhang Gedhe, dan Kendhang Ketipung)

- Demung, Saron, Peking

- Gong dan Kempul

- Bonang Barung dan Bonang Penerus

- Kenong, Kethuk, dan Kempyang

- Slenthem

- Gender

- Gambang

3. Laras dalam Gamelan Jawa

Gamelan Jawa dapat dibedakan menjadi dua laras (tangga nada/titi nada), yaitu Slendro dan Pelog. Menurut mitologi Jawa, gamelan Slendro lebih tua usianya daripada gamelan Pelog. Slendro memiliki 5 (lima) nada per oktaf, yaitu 12345 yang penyebutannya adalah $j i, r o, l u, m o$, nem dengan interval yang sama atau kalau pun berbeda perbedaan intervalnya sangat kecil. Sedangkan Pelog memiliki 7 (tujuh) nada per oktaf, yaitu 1234567 dengan penyebutan ji, ro, lu, pat, mo, nem, pi dengan perbedaan interval yang besar.

\section{B. Studi Eksisting}

Buku ini berisi konten untuk pengenalan alat musik tradisional yang ada di seluruh Indonesia. Penyampaiannya dengan cara pengelompokan cara memainkan alat musik, misalnya alat musik yang ditiup, digesek, dipetik, dan lain-lain. Kontennya adalah gambar dan penjelasan deskriptif mengenai bentuk, cara memainkan, dan asal-usul singkat. Penyajiannya termasuk simple dan terintegrasi. Visual yang digunakan bergaya ilustrasi sehingga menimbulkan kesan lucu dan ceria. Hal itu juga dapat dilihat dari warna yang bervariasi dan cerah.

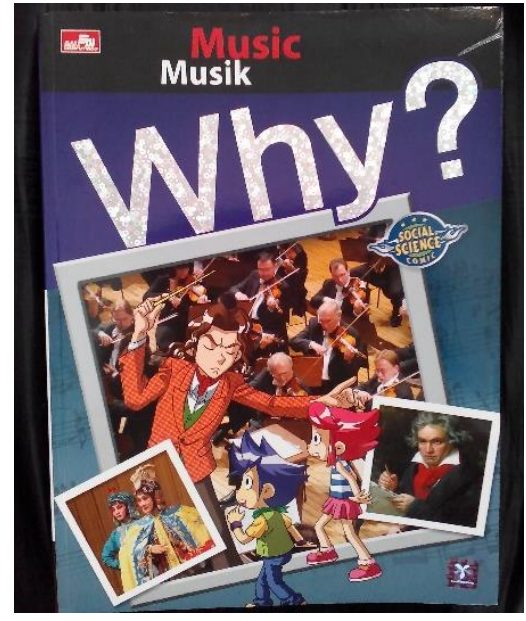

Gambar 3. Buku pengetahuan anak: Why: Musik?

Buku pengetahuan anak ini berisi pengetahuan umum tentang musik dari A hingga $\mathrm{Z}$. Pengetahuan-pengetahuan di dalamnya dikemukakan dengan cerita petualangan berbentuk komik. Secara visual, buku ini menggunakan teknik komik dengan gaya ilustrasi vektor. Warna yang dipilih adalah warnawarna yang kontras dan berkesan ceria. Buku ini memberi pengetahuan pada anak dengan pemunculan karakter sebagai penuntun anak dalam menyerap pengetahuan.

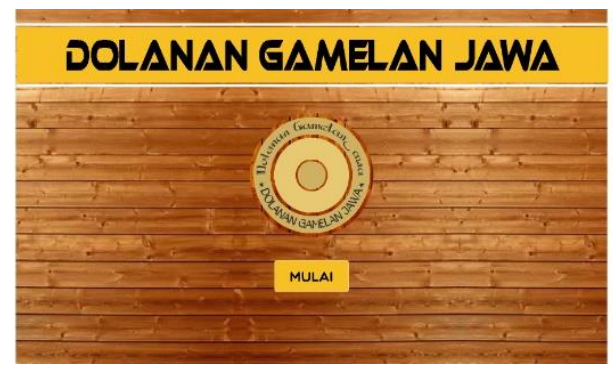

Gambar 4. Dolanan Gamelan Jawa

Dolanan Gamelan Jawa merupakan sebuah game berbasis Android yang memungkinkan penggunanya belajar memainkan instrumen-instrumen gamelan, dengan cara menekan layar yang bergambar instrumen gamelan untuk mengetahui bunyinya. Game ini juga menyediakan permainan untuk pengguna bermain gamelan sesuai not yang benar dari suatu lagu untuk mendapatkan score. Layout dan user interface yang digunakan sederhana dan tidak rumit. Visualnya menggunakan ilustrasi digital painting dengan background polos.

\section{METODE DAN ANALISA PENELITIAN}

\section{A. Metode Penelitian}

1. Focus Group Discussion

FGD dilakukan aebanyak dua kali dengan 6 anak kelas 3 dan 4 SD negeri, bertempat di SDN Semolowaru II/262 Surabaya, dan dengan 8 anak kelas 3 dan 4 SD swasta, bertempat di Sekolah Alam Insan Mulia Surabaya, untuk mengetahui hal-hal yang berkaitan dengan pengetahuan anak mengenai gamelan Jawa Timuran dan kaitannya dengan kurikulum yang digunakan di sekolah negeri dan swasta. 
2. Wawancara Mendalam

Wawancara mendalam dengan Dosen Sejarah Karawitan di Jurusan Seni Karawitan Sekolah Tinggi Kesenian Wilwatikta (STKW) untuk mengetahui hal-hal yang berkaitan dengan perkembangan yang terjadi pada objek penelitian, yaitu gamelan Jawa Timuran.

3. Observasi Lapangan dan Dokumentasi

Observasi dilakukan di Sekolah Tinggi Kesenian Wilwatikta (STKW) Surabaya untuk mendapat konten perancangan antara lain:

- Nama dan jenis instrumen pada gamelan Jawa Timuran

- Bentuk masing-masing instrumen

- Pengelompokan instrumen

- Bunyi yang dihasilkan masing-masing instrumen

- Cara memainkan masing-masing instrumen

- Peran instrumen-instrumen dalam permainan gamelan Jawa Timuran

\section{B. Teknik Sampling}

Target audiens dari perancangan media digital interaktif Gamelan Jawa Timuran ini adalah anak-anak usia 9-10 tahun yang sedang duduk di kelas 3 dan 4 SD.

\section{Segmentasi Geografis}

Berada dalam lingkup wilayah kota Surabaya.

\section{Segmentasi Demografis}

Berjenis kelamin laki-laki dan perempuan yang berusia 9-10 tahun. Populasi sedang menjalani pendidikan Sekolah Dasar kelas 3 atau 4. Berasal dari keluarga dengan keadaan ekonomi menengah ke atas.

\section{Segmentasi Psikografis}

Memiliki pengetahuan dasar mengoperasikan komputer, dalam satu hari mereka meluangkan waktu untuk menggunakan komputer, entah untuk bermain game, mengerjakan tugas sekolah, belajar, atau untuk keperluan lainnya. Selain itu populasi juga suka membaca buku-buku pengetahuan khusus untuk anak atau buku-buku cerita, juga bermain game.

\section{Karakteristik}

Memiliki rasa ingin tahu yang tinggi, berpikiran terbuka akan hal-hal baru dalam segala bidang, selalu ingin mengikuti perkembangan zaman, dan tidak cepat bosan.

\section{Sampel Responden}

- 14 anak umur 9-10 tahun

- Sedang duduk di kelas 3 dan 4 SD, sebagian bersekolah di SD negeri dan sisanya bersekolah di SD swasta.

- Laki-laki dan perempuan.

- Berdomisili Surabaya Timur.

Penelitian dilakukan dengan Focus Group Discussion (FGD). FGD pertama dilakukan dengan 6 orang anak yang duduk di kelas 3 dan 4 SD negeri, bertempat di SDN Semolowaru II/262 Surabaya. FGD kedua dilakukan dengan 8 orang anak yang duduk di kelas 3 dan 4 SD swasta, bertempat di Sekolah Alam Insan Mulia (SAIM) Surabaya.

\section{KONSEP DESAIN}

Perancangan media pengenalan gamelan Jawa Timuran ini berupa media digital interaktif yang memuat pengetahuan dasar tentang gamelan khususnya gamelan Jawa Timuran, mengandung audio dan juga visual. Konten akan dijabarkan dalam bentuk cerita yang interaktif. Tokoh dan karakter juga akan dimunculkan dengan peran memandu anak dalam menyerap konten cerita.

\section{A. Konsep Komunikasi}

Pengguna dari media interaktif yang akan dirancang adalah anak-anak usia 9-10 tahun sehingga bahasa yang digunakan dalam media adalah bahasa tidak baku dan bahasa serapan yang mudah dimengerti oleh anak dan tidak terkesan menggurui, namun tetap termasuk dalam bahasa yang sopan. Media diposisikan sebagai teman yang membutuhkan bantuan anak untuk menyelesaikan cerita. Media ini menyampaikan informasi dengan kata-kata dalam bentuk tulisan tanpa audio yang membacakan cerita tersebut.

\section{B. Konsep Visual}

Visual yang digunakan pada media digital interaktif ini adalah gaya gambar kartun, dengan melihat hasil survey terhadap sampel yang lebih menyukai ilustrasi daripada fotografi.

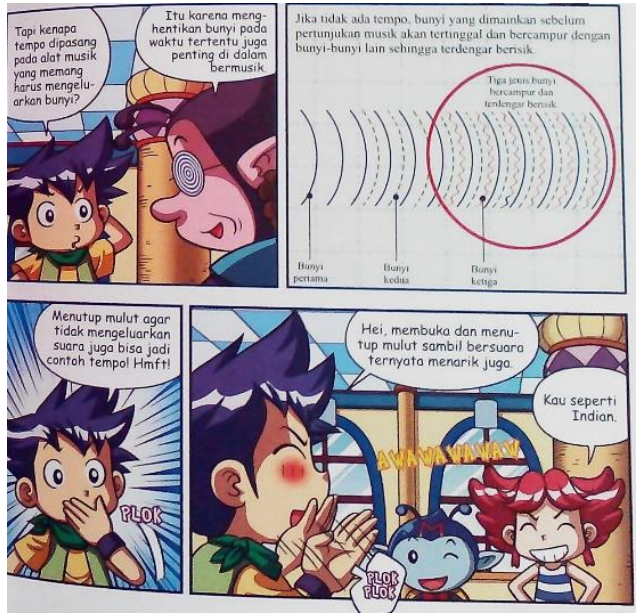

Gambar 5. Contoh gambar kartun

Untuk penyampaiannya informasi, penggunaannya mirip komik dengan pemunculan balon kata secara bergantian. Ada saat di mana ilustrasi karakter akan bergerak dengan teknik motion graphic untuk variasi sehingga bisa menjadi aksen. Tak hanya karakter, properti di sekitarnya pun ada saatnya bergerak dengan teknik yang sama.

Penggunaan warna pada desain media ini adalah dengan menggunakan banyak warna (colorful) sehingga anak tidak merasa terintimidasi oleh penggunaan warna tersebut, namun tetap menggunakan warna-warna lembut yang cenderung vintage dan pastel sehingga tidak menyakitkan mata apabila warna tersebut bertabrakan. Penggunaan konsep vintage colorful juga dipilih untuk menghilangkan kesan kuno yang terpatri dalam pikiran anak mengenai gamelan, namun masih memiliki karakteristik gamelan itu sendiri.

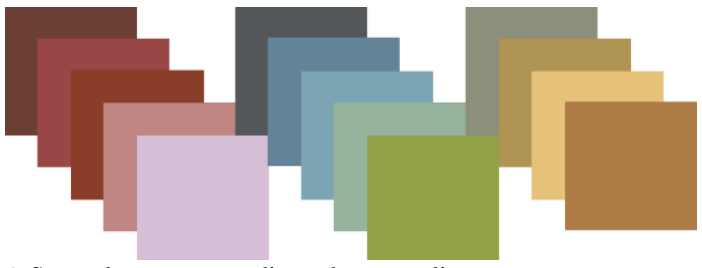

Gambar 6. Sampel warna yang digunakan penulis 


\section{PEMBAHASAN DESAIN}

\section{A. Tipografi}

Font yang digunakan berbeda menurut fungsinya, terdapat 4 jenis font yang digunakan penulis.

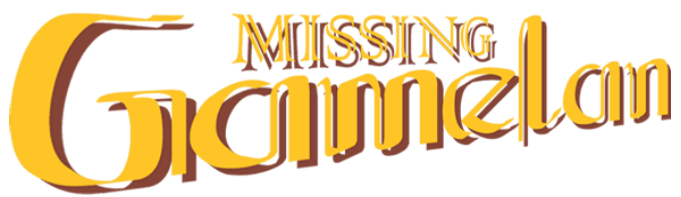

Gambar 7. Penggunaan font Jawa Palsu pada judul

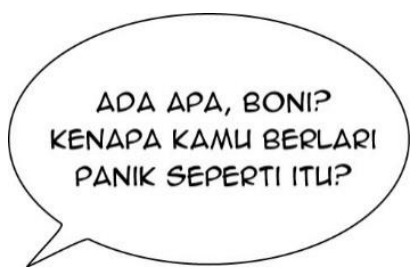

Gambar 8. Penggunaan font Anime-Ace pada balon kata

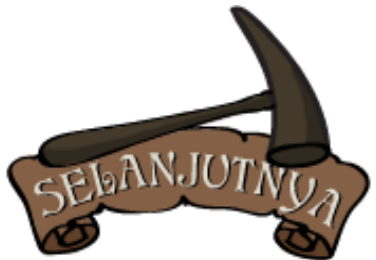

Gambar 9. Penggunaan font CAT CHILDS pada tombol

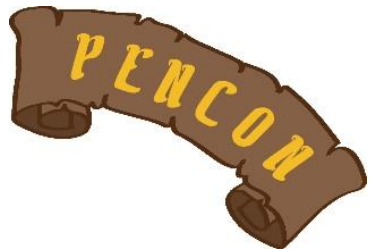

Gambar 10. Penggunaan font Creative Culture pada keterangan judul kelas

\section{B. Ilustrasi Latar}

1. Home dan Bank Info

Pada halaman utama/home, latar belakang diisi oleh ilustrasi pagar tembok Sekolah Gamel dengan aksen gapura Jawa yang berlubang membentuk instrumen-instrumen gamelan. Ilustrasi tersebut menggambarkan instrumen gamelan yang hilang dari sekolah. Dengan efek perwarnaan yang dibuat sedikit lebih realis dibandingkan latar belakang pada halaman lain untuk membangun kesan dramatis.

Untuk Bank Info yang tidak memiliki latar tempat, latar belakang dipenuhi oleh Ilustrasi outline berupa batik yang mengesankan "Jawa", dengan tingkat transparansi $21 \%$. Outline batik diterapkan tanpa menggunakan banyak warna untuk menjadi pemanis di balik elemen-elemen lainnya pada halaman Bank Info.
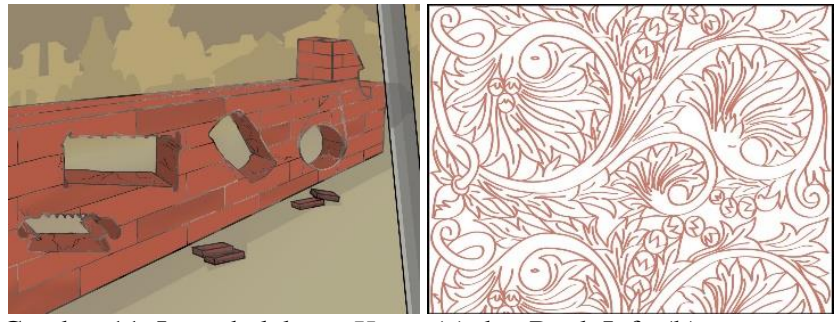

Gambar 11. Latar belakang Home (a) dan Bank Info (b)

2. Halaman Cerita

Pada halaman cerita, sebagian besar latar belakang diisi oleh ilustrasi latar tempat dari cerita tersebut, seperti halaman sekolah Gamel, depan ruang latihan, koridor sekolah, ruang CCTV, dan lain-lain. Angle diambil dengan memperlihatkan perspektif agar tampak kedalaman latar tempat.

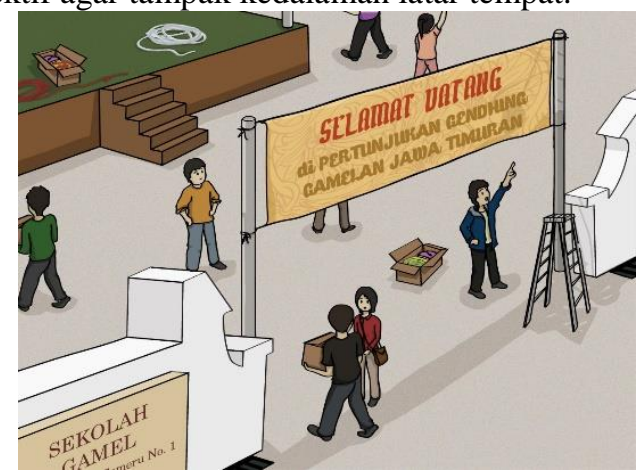

Gambar 12. Ilustrasi latar halaman Sekolah Gamel

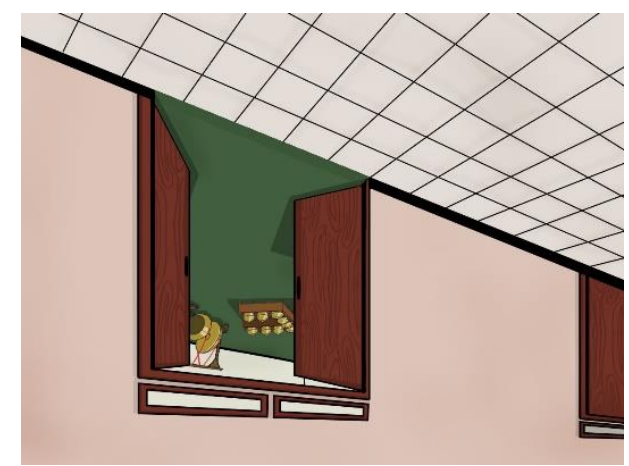

Gambar 13. Ilustrasi latar depan ruang latihan

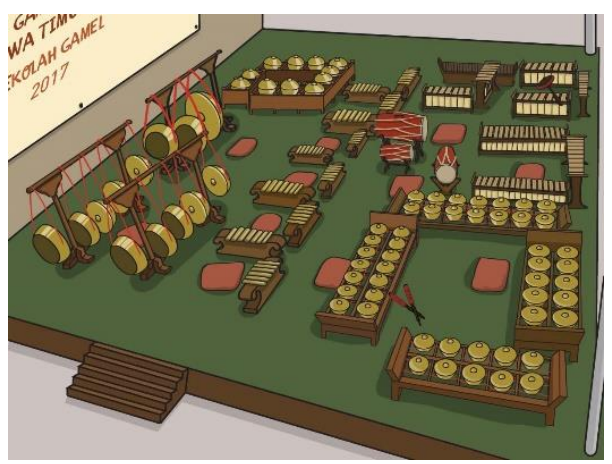

Gambar 14. Ilustrasi panggung pertunjukan

\section{Icon}

Ilustrasi dari tombol menggunakan bentukan instrumen gamelan dengan dilengkapi keterangan tombol di bawahnya sebagai penjelas fungsi tombol. 


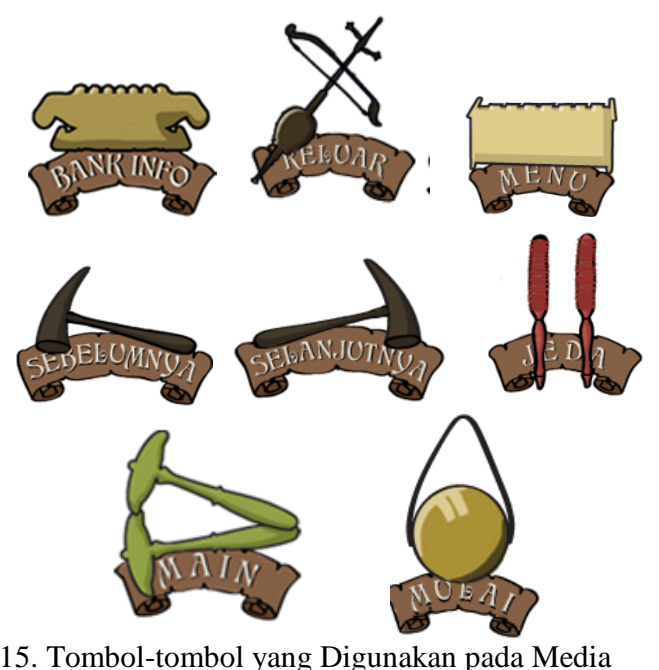

Gambar 15. Tombol-tombol yang Digunakan pada Media

\section{Motion Graphic}

Permainan digital interaktif Missing Gamelan menyisipkan motion graphic pada beberapa halaman, baik pada karakterkarakternya, latar, maupun balon kata percakapan.

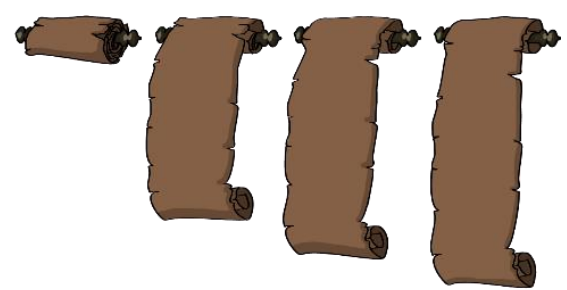

Gambar 16. Sequence Motion Graphic pada Properti

\section{E. Elemen Suara}

1. Backsound / Latar Musik

Home dan Bank Info

Menggunakan potongan lagu Gundul-Gundul Pacul oleh Jubing Kristianto yang menggunakan instrumen campuran dengan sentuhan modern untuk menghilangkan kesan kuno dan membosankan.

\section{Halaman Cerita}

Menggunakan potongan lagu instrumental Bubuy Bulan hasil re-aransemen Jubing Kristianto yang menggunakan instrumen tunggal yaitu gitar.

\section{Halaman Mini Game}

Menggunakan potongan lagu Bungong Jeumpa hasil rearansemen Addie MS dengan instrumen-instrumen orkestra.

\section{2. $S F X /$ Efek Suara}

Menggunakan suara pendukung dari jalannya cerita, seperti suara keramaian halaman sekolah, suara teriakan Boni, serta suara yang timbul oleh interaksi antara user dengan media, yaitu suara tombol yang diklik dan suara munculnya dialog dalam balon kata.

3. Bunyi Instrumen Gamelan

Menggunakan suara yang dihasilkan instrumen-instrumen pada gamelan Jawa Timuran, minimal pada 1 oktaf slendro dan 1 oktaf pelog, meliputi suara kendhang, gender, gambang, slenthem, peking, saron, demung, bonang, kenong, kempul, kethuk, kempyang, dan gong.

\section{KESIMPULAN DAN SARAN}

\section{A. Kesimpulan}

Desain final dari perancangan media digital interaktif Missing Famelan diujikan kepada target, yaitu anak-anak usia 9-10 1 hun yang dalam kesehariannya sudah terbiasa I lengoperasikan komputer/laptop. Berdasarkan hasil uji coba L..edia, maka dapat disimpulkan sebagai berikut:

- Visual yang disukai anak adalah visual berupa ilustrasi kartun dengan banyak macam warna cerah. Karakter dengan berbagai macam ekspresi pun disukai anak karena bersifat menghibur apa pun konteksnya.

- Untuk belajar mengenal sesuatu, sistem dengan cara menjadikan subjek sebagai sebuah jalan cerita yang sesuai der yan nalar anak adalah salah satu alternatif belajar yang meinudahkan, dengan ketentuan konten yang dimasukkan dalam cerita tersebut memiliki sistematika yang baik.

- Jenis permainan yang disukai adalah permainan yang memberi kesan tantangan, karena apabila disesuaikan dengan psikologi anak usia 9-10 tahun mereka menyukai sesuatu yang baru dan bersifat tantangan. Untuk jenis permainan yang berkaitan dengan gamelan, anak menyukai permainan membunyikan nada-nada pada instrumen gamelan sesuai contoh yang diberikan.

- Anak suka mengoperasikan media ini bergantian dengan teman. Sambil bermain, mereka berinteraksi secara langsung dengan berdiskusi tentang konten, saling menjelaskan apabila ada hal yang tidak dimengerti, dan saling membantu ketika bermain mini game.

\section{B. Saran}

Media digital interaktif Missing Gamelan menyajikan konten pengetahuan dasar mengenai gamelan Jawa Timuran yang mana sebenarnya gamelan merupakan sesuatu yang kompleks, sehingga tidak semua informasi bisa masuk ke dalam penyajian media. Penyelesaian dari permasalahan tersebut ada dua kemungkinan.

Kemungkinan pertama adalah dengan pembuatan series baru dari media dengan konten yang berbeda sehingga dalam satu media bisa menyajikan konten secara lebih spesifik. Sedangkan kemungkinan kedua adalah dengan memperpanjang cerita dalam Missing Gamelan dan diolah lebih runtut dan rapi sehingga semua konten informasi mengenai gamelan Jawa Timuran bisa masuk.

\section{DAFTAR PUSTAKA}

[1] Kartono, Kartini. Psikologi Anak (Psikologi Perkembangan). Bandung: CV. Mandar Maju. (1995)

[2] Broto, Gatot S. Dewa. (Februari, 2014). Riset Kominfo dan UNICEF Mengenai Perilaku Anak dan Remaja Dalam Menggunakan Internet. Artikel [online]. Available: https://kominfo.go.id/index.php/content/detail/3834/Siara n+Pers+No.+17-PIH-KOMINFO-2-

2014+tentang+Riset+Kominfo+dan+UNICEF+Mengenai +Perilaku+Anak+dan+Remaja+Dalam+Menggunakan+In ternet+/0/siaran_pers 